Marta Trębaczewska

(Szkoła Wyższa im. B. Jańskiego w Warszawie

Wydział Nauk Społecznych)

\title{
„Mater semper certa est"? Medycyna a kwestia rodzicielstwa
}

Gdyby Bronisław Malinowski żył dzisiaj, jego praca mogłaby okazać się znacznie trudniejsza za sprawą współczesnych osiagnięć medycyny. W swych pracach opisuje on bowiem matrylinearny system, w którym pokrewieństwo oraz wspólnych przodków ustala się po linii matki (po urodzeniu dzieci automatycznie stają się członkami grupy matki i pozostają w niej całe życie). Ma to określone konsekwencje związane z dziedziczeniem (nazwisk, przywilejów, rangi, majątku i in.), jak również z odpowiedzialnością za narodzone dziecko (vide funkcja ojca społecznego na Trobriandach, którym jest brat lub najbliższy męski krewny matki) czy z zawieraniem związków małżeńskich z własnymi dziećmi w skrajnych przypadkach.

System ten, jak większość systemów prawnych w tzw. cywilizacji zachodniej, opiera się na przekonaniu, że kwestia wydania na świat dziecka nie pozostawia watpliwości co do tego, że kobieta jest matka, co wyraża starożytna maksyma Mater semper certa est (Matka jest zawsze pewna). Jako że Pater semper incertus est (Ojciec nie zawsze jest pewny), dla ułatwienia i zachowania porządku społecznego współczesnego świata ustalono, iż Pater qui nuptiae demonstrant (Ojcem mąż matki), co rozwiązywało przez wieki sprawe praw i obowiązków rodzicielskich (z zaznaczeniem wszakże, że w określonych i uzasadnionych przypadkach kwestię ojcostwa można podać w wątpliwość, a macierzyństwa już nie).

Współczesna medycyna kwestionuje i obala tę podwalinę prawa rodzinnego. Poglądy, „że jedynie i wyłącznie matka wytwarza ciało dziecka" (Malinowski 1980: 148) i jako taka jest niezaprzeczalnie jego matka, oraz że fakt wydania na świat potomka jednoznacznie czyni kobietę matka, jak jest w polskim prawie - za sprawa rozwoju nauk biologicznych i medycznych nie wyczerpują już zagadnienia macierzyństwa i rodzicielstwa. Różnorodność konstelacji wynikających z możliwości medycyny (transplantologia, pozaustrojowe zapłodnienie) czy genetyki sprowadza 
dziś kwestię bycia rodzicem do poziomu komórkowo (dawstwo bądź donacja komórek jajowych i plemników)-narządowego (transplantacja czy wypożyczenie macicy), dla równowagi dodając czasem także wariant społeczny zawarty w obiegowym „ważne, kto wychowuje”. W praktyce oznacza to, że niemożliwe staje się udzielenie jednoznacznej odpowiedzi na pytanie: kto jest moja matka i ojcem? W świetle ostatnich doniesień uzasadnione wydaje się wznowienie dyskusji i - być może - redefinicja pojęcia macierzyństwa, ojcostwa i rodzicielstwa sensu largo. Okazuje się bowiem, że medycyna i nauki jej pokrewne rozwijają się szybciej niż prawo, czy zasady współżycia społecznego, wskutek czego ustalenie, kto i jakie ma prawa i obowiązki względem narodzonego dziecka staje się niewykonalne.

W skrajnej, hipotetycznej sytuacji możemy mieć do czynienia z następującymi okolicznościami: młoda kobieta pozostająca w związku z niepłodnym partnerem nie posiada macicy. Przyczyna może być zespół Mayer-Rokitansky-Küster-Hauser (wrodzony brak pochwy i macicy, pierwotny brak miesiaczki, prawidłowo rozwinięte jajniki i jajowody o prawidłowej czynności ${ }^{1}$ ) lub usunięcie macicy na skutek nowotworu. Nie można powiedzieć, że kobiety takie są bezpłodne - teoretycznie są, posiadaja normalnie funkcjonujace jajniki, jednak nie mogą być w ciąży i urodzić dziecka. Przyjmijmy, że z różnych powodów ${ }^{2}$ owa młoda kobieta nigdy nie zamroziła swoich komórek jajowych. Przyjaciółka decyduje się oddać jej swoja macicę $e^{3}$, aby ta mogła doświadczyć bycia ciężarną i urodzić dziecko (przez cesarskie cięcie). Z braku własnego jajeczka i niepłodności partnera kobieta korzysta z banku komórek jajowych i banku spermy (dawstwo komórki jajowej i plemników). Taki zarodek zostaje wszczepiony do „wypożyczonej”/ transplantowanej macicy (zostanie ona usunięta po porodzie). Pomijając wpływ leków immunosupresyjnych na rozwijajacy się płód, czyje będzie dziecko? Tej, która dała swoja komórkę? Tej, która ją nosi? Tej, która dała macicę? Czy też w dalszym ciagu stwierdzenie, że matką tego dziecka będzie ta, która je

\footnotetext{
${ }^{1}$ http://emedicine.medscape.com/article/953492-overview (dostęp: 9.02.2013).

${ }^{2}$ Teoretycznie do in vitro można użyć po prostu jej komórek jajowych, a następnie wszczepić zygotę do przeszczepionej macicy, lecz ,jeśli już porywać się w tej sytuacji na to, by zostać matka, to lepiej nie ryzykować, że się swoje wadliwe geny dziecku przekaże (dziedziczenie autosomalne dominujące) i w tym kontekście rozsądne jest zapłodnienie komórki jajowej od zdrowej dawczyni [...]. Z kolei kobieta po usunięciu macicy z powodu nowotworu rzeczywiście może potrzebować komórki jajowej innej kobiety, ale to dlatego, że po leczeniu chirurgicznym zwykle uzupełniająco stosuje się radioterapię lub chemioterapię i tu faktycznie, jeśli nie zamrożono komórek jajowych przed leczeniem, byłoby zwiększone ryzyko wystąpienia wad genetycznych u dziecka" (wywiad własny z lek. med. Anną Malinowska).

${ }^{3}$ www.rynekzdrowia.pl/Uslugi-medyczne/Przeszczepiono-corkom-macice-matek,123376,8. html (dostęp: 3.02.2013).
} 
urodzi, jest wystarczające? A co, jeśli ta zdecyduje się dziecko porzucić i w wyniku poszukiwań ustalona zostanie matka genetyczna? Czy jej (matki genetycznej) mąż będzie miał obowiązek utrzymywania owego dziecka do momentu, kiedy nie udowodni, że nie jest z nim spokrewniony (w polskim prawie domniemanie ojcostwa w związku małżeńskim do 300 dni po jego ustaniu $)^{4}$ ?

Takie i inne, dziś niewyobrażalne, ale z punktu widzenia medycyny nie niemożliwe sytuacje, zmuszaja do postawienia sobie pytania o istotę macierzyństwa i szerzej - rodzicielstwa. Być może na wstępie należałoby w ogóle zrezygnować $\mathrm{z}$ używania samego rzeczownika i zawsze dodawać określajacy je przymiotnik? W obliczu dokonań medycyny uzasadnione wydaje się doprecyzowywanie, z jakim typem rodzicielstwa mamy do czynienia: Czy jest to rodzicielstwo prenatalne czy postnatalne? Czy prenatalne to genetyczne (dawstwo komórek jajowych i plemników) czy fizjologiczne (akt rodzenia)? Czy postnatalne to społeczne, czy prawne (np. wspomniany obowiązek alimentacyjny)? Ponadto, typy te się nie wykluczaja - można być matka genetyczną i społeczna, ale już nie fizjologiczną. Można być matką fizjologiczna, ale nie genetyczną i nie społeczną. Przyjrzyjmy się kilku możliwym konstelacjom ${ }^{5}$ :

${ }^{4}$ Przepis mówiący o 300 dniach jest, w świetle możliwości zamrażania zarodków i donacji materiału genetycznego, bez sensu. Co bowiem w sytuacji, w której poczęte dziecko pochodzi - genetycznie - od dawno nieżyjącego dawcy (por.: Ojciec zza grobu: http:// dziecko.onet.pl/79504,6,9,ojciec_zza_grobu,artykul.html) (dostęp: 12.02.2013)? Czy, po ustaleniu genetycznych korzeni - obowiązek alimentacyjny przejma dziadkowie, tj. rodzice zmarłego?

„[...] Ojcem dziecka - zgodnie z art. 85, § 1 - jest mężczyzna, który obcował z matka dziecka między 181 a 300 dniem od urodzenia się dziecka. Tutaj, faktycznie pobrzmiewa archaiczność w konfrontacji z dawstwem plemników, ale z kolei art. 84 § 2 pozwala wytoczyć ojcostwo przeciwko nieżyjącemu domniemanemu ojcu w osobie kuratora wyznaczonego przez sąd opiekuńczy, natomiast jeżeli on żyje, to zgodnie z art. $77 \S 1$ wystarczy, by ukończył lat 16 i udowodniono jego ojcostwo względem spornego dziecka, a zostaje obarczony prawami i obowiązkami względem tego dziecka”. Korespondencja własna z Ewą Raczek, emerytowanym pracownikiem Katedry Medycyny Sądowej Śląskiego Uniwersytetu Medycznego w Katowicach, biegłym z zakresu genetyki sądowej w Sadzie Okręgowym w Katowicach.

${ }^{5}$ Podane przykłady absolutnie nie wyczerpuja zagadnienia: np. omawiane sa tu wyłacznie przypadki ciąży pojedynczych, choć możliwe są ciąże mnogie, gdzie każdy z płodów ma innych dawców materiału genetycznego, co zwielokrotnia możliwe konsekwencje (odpowiednio więcej możliwych ojców, matek, dziadków; wieloznaczność pojęcia rodzeństwo itd.). Osoby w nich wskazane pozostają w związkach małżeńskich, ma to na celu ukazanie wynikajacych z tego faktu praw i obowiązków. Nie można jednak zapominać o rozwiązaniach nienormatywnych - związkach wolnych, niesformalizowanych, homoseksualnych czy rodzinach monoparentalnych, które zagadnienie rodzicielstwa dodatkowo komplikuja. Przedmiotem rozważań nie sa kwestie procesu zapłodnienia (do zapłodnień może dojść w rezultacie aktu seksualnego lub pozaustrojowo). 
1. Kobieta ciężarna nosi $w$ sobie dziecko poczęte ze swojej komórki jajowej i plemnika jej męża. Wspólnie będa wychowywać dziecko po urodzeniu.

Matka fizjologiczna (będąca w ciąży) jest jednocześnie matką genetyczną (dziecko jest owocem jej komórki jajowej) oraz społeczna (wychowuje dziecko po urodzeniu, ma pełnię praw i obowiązków). Ojciec genetyczny (dawca plemnika) jest jednocześnie ojcem społecznym i prawnym.

2. Kobieta ciężarna nosi $w$ sobie dziecko poczęte ze swojej komórki jajowej $i$ plemnika mężczyzny będacego mężem innej kobiety. Dziecko będzie wychowywać dawca plemnika i jego żona.

Matka fizjologiczna jest jednocześnie matka genetyczna. Ojciec genetyczny pozostaje w związu małżeńskim z kobieta, która będzie matka społeczna, a jeśli matka fizjologiczna i genetyczna zrezygnuje ze swoich praw na jej rzecz w wyniku adopcji ze wskazaniem (legalnej formy przysposobienia), to zakres jej praw i obowiązków będzie taki, jak przewidziany dla matki z pkt 1 . Warto zwrócić uwagę, iż do momentu podjęcia jakichkolwiek dalszych działań prawnych za ojca dziecka uznaje się męża matki fizjologicznej, któremu przysługują i na którym spoczywają określone obowiązki (np. obowiązek utrzymania - ojciec prawny).

3. Kobieta ciężarna nosi $w$ sobie dziecko poczęte ze swojej komórki jajowej i plemnika znanego jej mężczyzny (dawstwo plemników, w tym także za sprawa zdrady matżeńskiej), niebędacego jej meżem. Dziecko będzie wychowywane przez kobiete $i$ jej męża.

Matka fizjologiczna jest również matką genetyczną i społeczną. Za ojca dziecka uważa się męża matki (jest on ojcem w świetle prawa oraz ojcem społecznym wychowującym dziecko). Nie jest ojcem genetycznym. Ojciec genetyczny może (w wyniku podjęcia odpowiednich kroków prawnych) stać się także ojcem społecznym (współwychowującym i z innymi obowiązkami, np. alimentacyjnym), co nie wyklucza ojcostwa społecznego męża matki dziecka.

4. Kobieta ciężarna nosi $w$ sobie dziecko poczęte ze swojej komórki jajowej i plemnika anonimowego mężczyzny. Dziecko będzie wychowywane przez kobiete i jej męża ${ }^{6}$.

\footnotetext{
${ }^{6} \mathrm{Tu}$ dodatkowo kwestia prawna ojcostwa: jeżeli mąż matki dziecka wyraził zgodę na inseminację swej żony heterologicznym (obcym) nasieniem, to zgodnie z art. $68 \mathrm{KRiO}$ nie może zaprzeczyć swemu ojcostwu względem tego dziecka, jeżeli zaś mąż matki dziecka został przez nia zdradzony, a podmiotowe dziecko jest owocem tej zdrady, to zgodnie z art. $63 \mathrm{KRiO}$ mąż matki może wytoczyć proces o zaprzeczenie ojcostwa. Korespondencja własna z Ewą Raczek.
} 
Matka jest genetyczna, fizjologiczna i społeczna, ojciec społeczny, niegenetyczny, z pełnia praw i obowiązków.

5. Kobieta ciężarna nosi w sobie dziecko poczęte z komórki jajowej nieanonimowej kobiety i plemnika męża owej kobiety (klasyczny przyktad surogatki). Dziecko będzie wychowywane przez dawców materiatu genetycznego.

Matka fizjologiczna nie jest matka genetyczną ani społeczną. Mąż matki nie jest ojcem genetycznym ani społecznym (choć $\mathrm{w}$ sensie prawnym pozostaje ojcem do momentu wszczęcia odpowiednich procedur prawnych). Rodzicami społecznymi sa rodzice genetyczni, z którymi dziecko jest obustronnie spokrewnione - brak jest jakiegokolwiek pokrewieństwa z matka fizjologiczna (co prawda obarcza je swoimi hormonami, które moga wpływać na rozwój dziecka, czego jednak nie można wykazać w późniejszych badaniach ${ }^{7}$ ).

6. Kobieta ciężarna nosi $w$ sobie dziecko poczęte z komórki jajowej nieanonimowej kobiety i plemnika męzczyzny będacego jej wtasnym mężem. Dziecko będzie wychowywane przez ciężarna i jej męża.

Matka fizjologiczna jest matką społeczna, ale nie genetyczną. Ojciec jest ojcem genetycznym, społecznym i prawnym. Matka genetyczna bez praw do dziecka w momencie jego urodzenia (vide przypis 12).

7. Kobieta ciężarna nosi $w$ sobie dziecko poczęte $z$ komórki jajowej anonimowej kobiety i plemnika mężczyzny będacego jej wtasnym mężem. Dziecko będzie wychowywane przez ciężarna $i$ jej męża.

Matka jest fizjologiczna i społeczna, nie jest matka genetyczną. Ojciec jest genetyczny, społeczny, pełnoprawny.

8. Kobieta ciężarna nosi $w$ sobie dziecko poczęte z komórki jajowej, nieanonimowej kobiety i plemnika anonimowego mężczyzny. Dziecko będzie wychowywane przez ciężarna i jej męża.

Matka fizjologiczna jest matką społeczną, ale nie genetyczną. Matka genetyczna pozostaje bez praw do dziecka w momencie urodzenia (vide przypis 12). Ojciec społeczny z pełnią praw, ale nie genetyczny $^{8}$. W przypadku uznania za matkę matki genetycznej,

${ }^{7}$ „P: Czyli nie są to zestawy hormonów ekskluzywne, tj. dzieci urodzone przez tą samą surogatkę nie będą miały żadnej «hormonalnej» cechy wspólnej pochodzącej od tej surogatki, żadnych hormonów, których zbadanie mogłoby udowodnić ich wspólne pochodzenie? O: Generalnie właśnie tak. Może sa jakieś dane, które mówią co innego, ale ja ich nie znam. Byłoby to ciekawe”. Wywiad własny z Magdaleną Nawara, adiunktem w Zespole Pracowni Genetyki Molekularnej IMID.

${ }^{8}$ Zgodnie z art. 68 heterologiczna inseminacja, na którą zgodził się mąż, czyni go ojcem i pozbawia możliwości zaprzeczenia ojcostwa. Fakt obcości genetycznej pozostaje jednak niezmienny i może istotnie wpłynąć na relację tegoż ojca z dzieckiem. Jednocześnie 
teoretycznie ojcem (do momentu zaprzeczenia) byłby mąż matki genetycznej, co stałoby w sprzeczności z konsekwencjami prawnymi zapłodnienia heterologicznego (zakładając, że anonimowość ojca genetycznego byłaby zachowana i ten nie domagałby się swoich praw do dziecka).

9. Kobieta ciężarna nosi $w$ sobie dziecko poczęte $z$ komórki anonimowej kobiety i plemnika anonimowego mężczyzny. Dziecko będzie wychowywane przez ciężarna $i$ jej męża.

Matka fizjologiczna i społeczna, niegenetyczna. Ojciec społeczny, niegenetyczny (vide przypadek 8).

10. Kobieta ciężarna jest genetyczna, fizjologiczna $i$ spoteczna matka dawczyni komórki jajowej. Dawca nasienia to maż dawczyni komórki. Dziecko wychowywane przez dawczynię komórki i jej męża. Fizjologiczna matka dziecka jest z nim częściowo spokrewniona genetycznie, gdyż jest również jego babką (matka zostaje surogatką dla córki, która nie może posiadać potomstwa). Ojcem częściowo genetycznym i prawnym pozostaje mąż matki fizjologicznej, czyli dziadek dziecka (do momentu zaprzeczenia lub adopcji przez dawców komórek). Ojcem społecznym i genetycznym jest mąż matki genetycznej, matką społeczna - matka genetyczna, która jest również (z racji urodzenia przez matkę fizjologiczną) siostrą dziecka. Matka fizjologiczna i jej mąż (rodzice matki genetycznej i społecznej), pozostając dziadkami dziecka, również uczestniczą w jego wychowaniu (Fuszara, Kurczewski 2007: 41-62).

Czy w świetle powyższego można jednoznacznie stwierdzić, kto jest rodzicem - kto ojcem, a kto matką? Czy można tu zastosować jakąś gradację - czy któreś rodzicielstwo jest ważniejsze niż inne? Zdaniem polskiego ustawodawcy - tak.

Polskie prawo - Kodeks Rodzinny i Opiekuńczy (KRiO) - jest w tym zakresie dalece niedoskonałe. Pominąwszy fakt, że Polska nie ratyfikowała Europejskiej Konwencji Bioetycznej przyjętej przez Komitet Ministrów Rady Europy w 1997 r., co pozwoliłoby używać jej jako narzędzia prawnego, to - ignorując rosnace potrzeby społeczne - do dziś nie sformułowano jakiejkolwiek ustawy o zapłodnieniu pozaustrojowym (in vitro) (Raczek 2009: 134-135). Ustawodawca wykazał się jednak pewnym uznaniem dokonań medycznych i biotechnologicznych, podejmując w 2008 r. próbę nowelizacji dotychczas obowiązujących przepisów.

jednak ustawodawca stwarza możliwość zaprzeczenia tego ojcostwa (art. 70 § 1), ale przyznaje prawo wyłacznie dziecku, wprowadzając niczym nieuzasadnione ograniczenie czasowe do 3 lat od momentu osiagnięcia pełnoletności. 
Wydaje się jednak, że przepisy te wprowadzaja w rzeczywistości więcej zamieszania, generuja nierozwiązywalne konflikty oraz dyskryminuja i naruszaja gwarantowana konstytucyjnie godność.

Kluczowym jest przepis art. $61^{9} \mathrm{KRiO}$, w myśl którego matką dziecka jest kobieta, która je urodziła. Tym samym ustawodawca odbiera prawa do dziecka dawczyniom materiału genetycznego oraz kobietom, które dziecko chciałyby wychować. Więź biologiczna, jaka może (ale przecież nie musi) wytworzyć się pomiędzy płodem a ciężarną, została przez ustawodawce przyjęta jako aprioryczna i pozytywna oraz ważniejsza od więzi psychicznej i emocjonalnej pomiędzy dawczynią materiału genetycznego (lub niespokrewniona genetycznie kobieta) pragnąca otoczyć je opieką i uczuciem. Przyjęto, że owa więź powstaje bez uwzględnienia czynników, które na nią i jej zaistnienie wpływają. Przez urodzenie nie rozumiemy dzisiaj wyłącznie przejścia dziecka przez kanał rodny kobiety, co wiąże się z wysiłkiem i mogłoby uzasadniać intencje ustawodawcy, jako że powszechnie odbywa się ono także przez cesarskie cięcie. Ponadto, nauka pozwala dziś ratować płody w 20 tygodniu trwającej 40 tygodni ciąży, a niebawem zapewne granica ta jeszcze się obniży. Czy 5 miesięcy ${ }^{9}$ ciąży zakończonej cesarskim cięciem i umieszczeniem dziecka w inkubatorze wystarczy, aby więź się wytworzyła i by kobiete nosząca płód w brzuchu uznać za matkę? W komentarzach do nowelizacji K.R.O. (Szczepaniak 2009) często pojawia się opinia, iż 9 miesięcy ciąży, badania USG, słuchanie tętna płodu i wyczuwalne ruchy dziecka sa wystarczajacymi przesłankami do powstania uzasadniającej przepis więzi pomiędzy nosicielką i dzieckiem. Wydaje się, że ustawodawca pominą konsultacje z kobietami noszacymi dzieci będace rezultatem przestępstwa (gwałt), kobietami noszacymi niepełnosprawne dzieci czy kobietami, które rzekomo chce chronić, a więc surogatkami. W wywiadach przeprowadzonych z kobietami, które więcej niż raz zdecydowały się oddać urodzone przez siebie dziecko, zauważyć można silny wpływ determinacji i motywacji na ową więź:

[...] bardzo ubolewam, że nasze państwo tak postępuje z ludźmi. A w szczególności cierpia te bezptodne kobiety, dla mnie to jest chore po prostu. Nie zgadzam się $z$ tym prawem, że za matke jest uznawana kobieta, która rodzi komuś, choć rozumiem co niektórych ludzi, którzy pytaja, jak można oddać dziecko? 9 miesięcy nosić pod sercem i oddać? Ale tak pytaja ci, co nie widzieli tego, co ja. Niech mi pani wierzy, jak na własne oczy zobaczyłam, ile $w$ klinice pary ptacity za zabiegi in vitro, za hormony... nie mogtam $w$ to

\footnotetext{
${ }^{9} 5$ miesięcy przy założeniu, że kobieta wie o ciąży od momentu poczęcia - zwykle ciążę potwierdza się około 6 tygodnia, co daje 14 tygodni (3,5 miesiąca) na wytworzenie się więzi.
} 
uwierzyć. Tysiace, żeby mieć ukochane dziecko. Zapożyczaja sie u rodzin, domy pod zastaw daja, żeby za nie... a jak nie wyszło, to żeby spróbować jeszcze raz. I to, przez co te kobiety przechodza - cięte, ktute, faszerowane jak kaczki, z pracy sie zwalniaja, życia nie maja, żeby tylko to dziecko... Dla mnie to byto tak, że ja musze oddać to dzięciatko, bo czekaja rodzice prawdziwi co całe życie czekali na ta kruszynke, że będzie kochane, nic nie zabraknie jemu. Może mi pani nie wierzyć, ale miałam świadomość, $\dot{z}$ e nie moge sie przywiazać $w$ żaden sposób emocjonalnie ani psychicznie. [...] może by byto trudniej, gdyby byto z mojego jajeczka, nie wiem... ale na to sie nie godze. Ja naprawde chce pomagać. Jak ta surogatka $z$ Anglii, co sama najpierw nie mogta i surogatka jej urodziła, a pózniej ona sama zaszła $w$ ciaże 3 razy! I teraz sama jest surogatka $i$ rodzi innym, bo ma taki dtug do sptacenia, żeby i innym radość dać za jej radość. I nie bierze za to pieniędzy, bo tam takie prawo. Nasze prawo jest chore po prostu. [...] Nie kontaktuje sie, nie robiłam zdjęć, z USG wszystko oddatam. Na wszelki wypadek. Wiem, że tak jest dobrze. One przecież sa u swoich rodziców, do nich podobne i oni je kochaja nad życie (S1).

Czy się zwiazuje jakoś... no jakoś się zwiazuję, bo jestem w ciaży, a żeby przebiegata dobrze, to muszę $i$ uważá na jedzenie, $i$ na spanie, $i$ na leki na goraczke. Więc jak wiem, że to dla tego dziecka, to jakoś się zwiazuję. Ale Pani pyta, czy kocham. To ja powiem tak: kochanie nie przychodzi dlatego, $\dot{z}$ e jest się w ciaży. Pokocha Pani, jak pokarmi, poprzewija, poprzytula. A to już będzie robić ich mama, nie ja. Ja kocham swoja trójkę i dla nich to robie, to jest moja więź z dzieckiem. A nie, że byto w brzuchu $(\mathrm{S} 2)^{10}$.

Ustawodawca założył jednak, że każda kobieta w ciąży związuje się pozytywnie z noszonym przez siebie dzieckiem, pomijajac opinie niepasujace do romantycznego wyobrażenia. Pomija również fakt, iż w przypadku braku pokrewieństwa genetycznego ciężarnej po wyjściu ze szpitala, niezwykle trudno będzie udowodnić (lub ona nie udowodni) związku pomiędzy nią a pozostajacym w szpitalu dzieckiem ${ }^{11}$. A przede wszystkim pomija fakt przywiązania emocjonalnego pomiędzy dzieckiem a kobieta faktycznie je wychowujaca. Ustawowe rozumienie słowa „matka” sprowadza macierzyństwo do udostępnienia powłok brzusznych. Jest matka w świetle polskiego prawa ta, której powłoki brzuszne

\footnotetext{
${ }^{10}$ Wywiady własne w ramach realizowanego autorskiego projektu badawczego „Społeczne funkcjonowanie osób niepłodnych”. S1: lat 31, samotna, matka 12-letniego syna. S2: lat 35, mężatka, matka 9-letniej córki i 7-letnich bliźniaków.

${ }^{11} \mathrm{~W}$ określonych przypadkach, jak np. przebyte w okresie ciąży choroby metaboliczne (cukrzyca, zaburzenia funkcji tarczycy), zakaźne (np. HIV, WZW, toksoplazmoza) czy zakażenia okołoporodowe, szansa na udowodnienie porodu jest wysoka, lecz maleje wraz z upływem czasu (np. swoiste przeciwciała matczyne zanikaja w okresie 6-18 miesięcy po porodzie). Wywiad własny z lek. med. Anna Malinowska.
} 
otaczały macicę (która niebawem nie będzie musiała należeć do właścicielki brzucha), w której rozwijał się obcy genetycznie zarodek.

Twierdzenie o wyższości faktu noszenia w brzuchu dziecka nad relacja pomiędzy tym dzieckiem a dawcami materiału genetycznego jest ponadto dyskryminujace dla samych kobiet oraz piettnujacce i niezwykle krzywdzące dla matek niepłodnych. Nowelizacja KRiO przekreśla rodzicielstwo genetyczne kobiety, choć uważa je za oczywiste w przypadku mężczyzny - nawet, jeśli dziecko jest owocem gwałtu, to gwałciciel matki jest ojcem. Tenże gwałciciel po latach może domagać się uznania swego ojcostwa i na tej podstawie wnioskować o alimenty - pomimo tego, iż nie brał jakiegokolwiek udziału w wychowaniu dziecka. Naturalnie należy tu liczyć na zdrowy rozsądek orzekającego wówczas sędziego, co nie zmienia faktu, iż obarczenie dziecka taką wiedzą oraz procedury sądowe istotnie zaburza jego życie.

Przepisy dyskryminuja także kobiety dotknięte nieplanowana bezdzietnością. Informacja o niemożności posiadania własnego potomstwa dla kobiety, która tego pragnie, jest przyczyna jej nieszczęścia o podłożu psychicznym, emocjonalnym i egzystencjalnym. Korzystając z możliwości dawanych jej przez dzisiejsza medycynę, pragnie wychowywać i kochać dziecko, będace jej genetycznym potomkiem, po drodze otaczajac opieka matke zastępcza, która je urodzi i uczestnicząc w całej drodze od poczęcia aż do narodzin. Nawiązanej wówczas więzi nie można zaprzeczyć ( $\mathrm{w}$ podobnej sytuacji znajduja się przecież ojcowie i ich więzi nikt nie podważa), co jednak ustawodawca czyni. Twierdząc, że w dalszym ciagu nie jest ona matka po raz kolejny udowadnia kobiecie, że nie jest pełnowartościowa. Ponadto, nawet $\mathrm{w}$ sytuacji aktualnie dopuszczalnej przez prawo, a więc adopcji swojego genetycznego potomka, ustawodawca naraża ja na życie w nieustajacym strachu o trwałość swojej rodziny, a to za sprawa art. $61 \mathrm{KRiO}$. Istnieje bowiem możliwość prawna zaprzeczenia macierzyństwa. Przesłanka materialnoprawna dochodzenia zaprzeczenia macierzyństwa jest niezgodność aktu urodzenia z rzeczywistością biologiczna polegająca na braku więzi biologicznej wynikajacej z urodzenia dziecka, nie zaś braku więzi genetycznej. Powództwo o zaprzeczenie macierzyństwa może zostać wytoczone, jeśli w akcie urodzenia wpisana jest matka, która dziecka nie urodziła (Golec-Grzymek 2009). Ustawodawca stworzył taką możliwość w intencji ochrony matek-surogatek pragnacych jednak zatrzymać dziecko, po raz kolejny pomijając kobiety niemogace urodzić własnych dzieci ${ }^{12}$. Nawet

\footnotetext{
12 Tym samym ustawodawca otworzył możliwość nieograniczonego handlowania dziećmi: matka-surogatka może szantażować genetycznych rodziców i domagać się nieustających gratyfikacji, argumentując swoje żądania możliwością odebrania dziecka.
} 
przy legalnie przeprowadzonej procedurze przysposobienia swego genetycznego dziecka, matka (genetyczna) może być swych praw pozbawiona przez matke fizjologiczna ${ }^{13}$. Przepis, co prawda, mówi o danym matce fizjologicznej czasie sześciu miesięcy od porodu, ale nie wspomina o zakazie informowania przez nia dziecka o fakcie wydania go na świat i jednocześnie daje dziecku aż 3 lata od momentu osiagnięcia pełnoletności na zaprzeczenie macierzyństwa matki ${ }^{14}$, z której komórki powstało i która je przez ten czas obdarzała uczuciem i opieka. Tym samym naraża ją na życie w niepewności i ciagłej obawie, co może przekładać się na relacje wewnattrzrodzinne. W obliczu skutków społecznych i prawnych wynikajacych z zaprzeczenia macierzyństwa jest to obawa uzasadniona. Po pierwsze, ustaje władza rodzicielska dotychczasowej matki, zanika wzajemny obowiązek alimentacyjny (i opiekuńczy) oraz ustawowe dziedziczenie (w tym nazwiska). Sytuacja dotknie nie tylko rodziców i dziecko, ale spowoduje szersze konsekwencje wynikające z faktu, iż na rodzinę składają się zwykle także dziadkowie, wujostwo, rodzeństwo i inni krewni. Po latach może więc okazać się, iż rodzeństwo nie jest nawet przyrodnie, a ciotki to obce osoby. Czy będą wówczas mogły domagać się rekompensaty za nakłady finansowo-emocjonalne (np. opieka czy podarunki) poniesione w wyniku celowego wprowadzenia w błąd? I kto miałby wówczas być ich adresatem?

Zaprzeczenie macierzyństwa skutkuje również anulowaniem prawnych domniemań: ojcostwa (na podstawie art. $85 \mathrm{KRiO}$ ), domniemania, że ojcem dziecka jest mąż matki czy uznania ojcostwa na podstawie uznania dziecka za zgoda matki. Sytuacja prawna dziecka będzie wówczas wymagać ponownej regulacji prawnej w postaci procesów o ustalenie macierzyństwa i/lub ojcostwa.

Ustawodawca jest jednak arbitralny i nieprzejednany: matka jest ta, która urodziła, cokolwiek to współcześnie może oznaczać. To rozwiązanie niewatpliwie satysfakcjonujace dla Trobriandczyków.

${ }^{13}$ Udowodnienie macierzyństwa matki fizjologicznej - owej więzi biologicznej - odbywa się poprzez wykazanie, że to ona wydała dziecko na świat. W przypadku porodów domowych bez obecności lekarza, a także wraz z upływem czasu szanse na udowodnienie porodu i powiąanie go z konkretnym dzieckiem maleją. Jedynie pokrewieństwo, jakie może być ustalone, to pokrewieństwo genetyczne.

${ }^{14}$ Dopuszczalne jest zaprzeczenie macierzyństwa przez samo dziecko przeciwko kobiecie wpisanej w akcie urodzenia dziecka jako jego matka; przez biologiczna matkę dziecka przeciwko kobiecie wpisanej w akcie urodzenia dziecka jako jego matka i przeciwko dziecku; przez kobietę niebędącą matką, a wpisaną do aktu urodzenia jako matka dziecka przeciwko dziecku; przez mężczyznę, którego ojcostwo zostało ustalone z uwzględnieniem macierzyństwa kobiety wpisanej w akcie urodzenia dziecka oraz przez prokuratora. 
Czy jednak wystarczajace w obecnej sytuacji? Spójrzmy na to $\mathrm{z}$ innej perspektywy: jeśli do uznania macierzyństwa niepotrzebne jest pokrewieństwo genetyczne - prawo w tym względzie jednoznacznie dyskryminuje kobiety, odbierając im tę możliwość, choć dopuszcza ja dla mężczyzn (Raczek 2009: 134-135) - to w jaki sposób ustalić pochodzenie dziecka porzuconego przez niespokrewniona surogatke (matkę zastępcza)? Nie wspominając nawet szerzej o sytuacjach losowych ratujacych zdrowie i życie (transfuzje, przeszczepy) czy konieczności identyfikacji zwłok lub ich części. Nowe prawo przekreśla macierzyństwo genetyczne, „wprowadza nowa paremię Mater est quam gestatio demonstrant, która wyraźnie uznaje wyższość aktu rodzenia nad aktem stworzenia [...], naraża na uniemożliwienie ustalenia pochodzenia dziecka od matki, gdyż wszystkie artykuły nowego k.r.o. o ustalenie i zaprzeczenie macierzyństwa zasadzaja się na akcie urodzenia dziecka, a nie na jego faktycznym genetycznym przodku [tu: matce]" (Raczek 2009: 134-135), a ponadto - co paradoksalne - ustanawia matka dziecka kobietę, która nie jest jego żadną krewną (nawet w linii bocznej), co definiuje art. $61^{7} \S 1$ : Krewnymi w linii prostej sa osoby, z których jedna pochodzi od drugiej. Krewnymi w linii bocznej sa osoby, które pochodza od wspólnego przodka, a nie sa krewnymi w linii prostej. Wydaje się, że ustawodawca nie przewidział wielu możliwych rozwiązań, w tym wielokrotności bycia surogatka-matką zastępcza (jeśli to określenie w ogóle będzie jeszcze adekwatne). Jeśli surogatka zdecyduje się na urodzenie kilkorga dzieci pochodzących od różnych dawców komórek, to w myśl przepisów będzie ich matka. Oznacza to, że owe dzieci będą rodzeństwem ${ }^{15}$, a w myśl art. 58 § 1 i 107 § $2 \mathrm{KRiO}$ rodzeństwo powinno wychowywać się wspólnie. Jeśli jednak dawcy materiału genetycznego i matka zastępcza zdecydują się na adopcję ze wskazaniem rodziców genetycznych i sąd się do wniosku przychyli, to każde z dzieci urodzonych z tej samej matki (co czyni je rodzeństwem)

${ }^{15}$, „[...] proszę pamiętać, że to jest mój wywód, zgodnie z art. 61 (z indeksem górnym 9) KRiO: matką dzieci będzie ta, która urodziła, w tym przypadku surogatka, użyczająca swego brzucha, a więc dzieci te, jako urodzone przez tę samą matkę to rodzeństwo. I tu druga część wywodu: zgodnie z tymże, że KRiO, ale z jego art. 61 (z indeksem górnym 7) § 1: „Krewnymi w linii prostej są osoby, z których jedna pochodzi od drugiej. Krewnymi w linii bocznej sa osoby (a rodzeństwo to krewni w linii bocznej, naturalnie pomijam szczegółowość relacji), które pochodzą od wspólnego przodka, a nie sa krewnymi w linii prostej”, czyli nasze rodzeństwo z art. 61 ( indeksem górnym 9) nie jest rodzeństwem, bo nie pochodzi od wspólnego przodka - ich materiał genetyczny jest „różnoźródłowy”. Zdecydowana sprzeczność. Zatem w oparciu o obowiązujacy KRiO ich pokrewieństwo jest nie do rozstrzygnięcia”. Korespondencja własna z Ewą Raczek. 
będzie dla pozostałych obce i niespokrewnione ${ }^{16}$. Wspólnego pochodzenia nie będą w stanie wykazać żadne badania, dzieci nie będzie łączyć nic za wyjątkiem tego, że miały wspólną matkę fizjologiczną.

$\mathrm{W}$ tej samej części KRiO, odnoszącej się do kontaktów z rodzeństwem, znajduje się także przepis dotyczacy kontaktów dziecka z dziadkami i powinowatych w linii prostej (art. $113 \mathrm{KRiO}$ ). Jaki model rodziny powstanie, jeśli każdy z dziadków, wujów czy ciotek zacznie rościć prawa do narodzonego dziecka? Jak ich wówczas tytułować? Czy również przez wskazanie charakteru spokrewnienia czy pochodzenia (babcia genetyczna)?

Czy społeczeństwo jest gotowe na adaptację osiagnięć biologii i medycyny i wypracowanie nowych standardów zachowania (np. biologiczne potomstwo par homoseksualnych, które legalnie wychowują) ${ }^{17}$ ? Jakie sa możliwe tego konsekwencje? Czy wypracujemy nowy model rodziny, np. 3 + dzieci, gdzie przez 3 rozumie się biologicznego i społecznego ojca w jednej osobie oraz dwie matki - obie społeczne, z których jedna nosi (matka fizjologiczna) zapłodnione przez ojca jajeczko drugiej (matka genetyczna), której dawca plemnika jest mężem, co rozstrzyga większość kwestii spornych?

$\mathrm{Na}$ te i inne pytania odpowiedź winny dać badania socjologiczne, dotyczące analizy społeczeństw, jak również psychologiczne, skupione raczej na jednostkach, a więc na rodzicach zaangażowanych $\mathrm{w}$ proces przyjścia na świat dziecka i na samym dziecku, którego tożsamość może stać pod znakiem zapytania (brak odpowiedzi na pytanie o korzenie). O zmiany społeczne i legislacyjne już dziś walczą osoby dotknięte nieplanowaną bezdzietnościa, organizując kampanie społeczne dotyczące „adopcji prenatalnej"18, a więc dawstwa i biorstwa komórek. Wbrew polskiemu ustawodawcy zakładają oni, że zarówno rodzice prenatalni, jak i postnatalni maja swoje prawa, a dziecko poczęte w wyniku takich zabiegów ma prawo do godności osobistej, na którą składa się również prawo znajomości swojego pochodzenia.

\footnotetext{
${ }^{16} \mathrm{~W}$ przypadku czynów kazirodczych - zarówno pomiędzy rodzeństwem, jak i rodzicami i dziećmi - czy w dalszym ciagu będą one kazirodcze?

17 „Elton John oraz jego partner David Furnisch doczekali się kolejnego dziecka. Nowonarodzone dziecko to drugi potomek brytyjskiego muzyka i kanadyjskiego producenta oraz reżysera filmowego. Pierwszy syn homoseksualnej pary przyszedł na świat w grudniu 2010 r. i ma na imię Zachary. Drugie dziecko urodziła ta sama surogatka z Kalifornii, która urodziła parze pierwszego syna”. Źródło: www.wprost.pl/ar/383834/ Elton-John-zostal-kolejny-raz-ojcem/ (dostęp: 9.02.2013).

${ }^{18}$ Por.: kampania „Powiedzieć i rozmawiać” www.nasz-bocian.pl/powiedziecirozmawiacglowna (dostęp: 7.02.2013); www.edziecko.pl/edziecko/1,80348,12486266, Adopcja_ prenatalna_o_k.r.o.k_przed_wazna_decyzja.html (dostęp: 7.02.2013).
} 
Bronisław Malinowski część swojej pracy badawczej poświęcił zagadnieniu ojca społecznego jako tego, który faktycznie ma wpływ na dziecko. Z takim rozumieniem ojcostwa, a także szerzej - rodzicielstwa w ogóle - z pewnościa zgodza się rodzice adoptujacy i przysposabiający dzieci. Każdy socjolog chciałby, aby to właśnie rodzicielstwu społecznemu przypisywać największe prawo do tytułowania się ojcem i matką. Niestety, genetyka ze swoimi badaniami rozdzielonych w dzieciństwie bliźniąt jednojajowych (Fraga i in. 2005) udowadnia, że pochodzenie genetyczne jest równie ważne. Jest w człowieku jakiś atawizm i jakiś niesprecyzowany bliżej instynkt rozprzestrzeniania i zostawiania w populacji swojego materiału genetycznego, który wykorzystywany w różnych teoriach pozwalał tłumaczyć szereg zjawisk (np. skłonność do zdrady). Nie można go pomijać i teraz, w rozważaniach na temat rodzicielstwa - jego istoty i wariantów tworzonych przez współczesne nauki biologiczne i medyczne. Gdyby niebawem okazało się, że do rozwoju poczętego dziecka nie jest już potrzebne ciało matki, to właśnie pokrewieństwo genetyczne zapobiegnie handlowi noworodkami z wylęgarni lub przypadkowemu rodzicielstwu pod pozorem wyższości rodzicielstwa społecznego.

Warto jednak pamiętać, że geny nie są wyłącznym determinantem tego, kim jesteśmy. Geny dają skłonności, które otoczenie może eliminować lub wzmacniać. Dlatego to, co nas determinuje najbardziej, to ludzie, którzy nas otaczaja. To rodzic społeczny ma faktyczny wpływ na wychowywane dziecko. Znajomość jego backgroundu genetycznego może być co najwyżej traktowana jako wytłumaczenie dla swoich niepowodzeń/powodzeń wychowawczych i umiejętności/konieczności wybaczania (vide syn marnotrawny). Co jednak nie znaczy, że dziecko powinno być pozbawione wiedzy o swoim pochodzeniu i tym, kto je urodził.

A co na to Trobriandczycy? Wydaje się, że maja doskonale rozwinięte mechanizmy wyparcia i zaprzeczenia - po prostu nie przyjmuja do wiadomości wiedzy zagrażającej trwałości ich kultury. Skoro nie łącza prokreacji z poczęciem, to jest szansa, że - na swoje szczęście i spokój - nie będą sobie zawracać głowy dywagacjami komórkowo-narządowymi. I wcale nie musi to wynikać $\mathrm{z}$ ich niechęci do nauki, ale z chęci do utrzymania podwalin swojej kultury oraz spójności i ciagłości społeczeństwa. Takie podejście może być niezrozumiałe jedynie dla tych, którzy stawiają dobro jednostki nad dobrem ogółu. U Trobriandczyków (przynajmniej tych z czasów Malinowskiego) jest inaczej. Nie oznacza to, że nie ma tam kobiet niepłodnych (problem niepłodności mężczyzn nie istnieje $\mathrm{w}$ związku z możliwością posiadania przez 
kobietę wielu partnerów seksualnych) - zapewne sa i sa przez społeczeństwo akceptowane, skoro Malinowski nie poświęca im w swych pracach uwagi. Zapewne znajduja się dla nich inne, nie mniej ważne niż rodzicielska, funkcje plemienne/społeczne. Akceptuje się swa niemożność posiadania potomstwa i sublimuje ja w innych dziedzinach życia społecznego. Dlaczego? Ponieważ indywidualna potrzeba zaspokojenia potrzeby macierzyństwa mogłaby skutkować poważnymi konsekwencjami dla ogółu. Rezygnuje się więc z niej, bądź wyklucza się ze społeczności i opuszcza teren.

Wydaje się, że na polskim gruncie takie rozwiązanie jest nie do zaakceptowania. W przeciwieństwie do Szwedów, którzy zakazuja donacji jajeczek z uwagi na przyszłe problemy, jak te, o których mowa $\mathrm{w}$ niniejszym artykule, a także $\mathrm{z}$ uwagi na psychiczne konsekwencje poczętego w ten sposób dziecka (Saldeen 2000: 193-194) ${ }^{19}-$ my uważamy, że jesteśmy ważni przede wszystkim jako indywidua, niezależne jednostki. Być może źródeł takiego podejścia należy upatrywać w polskiej historii obarczonej zaborami i systemem totalitarnym, gdzie każda próba zaznaczenia swojej odrębności była tłumiona. Być może dlatego, dziś wyraźnie definiujemy swoją indywidualność i swoje jednostkowe potrzeby, w tym potrzebę rodzicielstwa ${ }^{20}$. Chcemy ja realizować, korzystając z najnowszych osiagnięć medycyny. Do tego i od tego mamy prawo. Jednakże prawo i medycyna nigdy nie będą podazżać tym samym tempem, bo inna jest ich specyfika, skutkiem czego prawo zawsze będzie pozostawać w tyle. Rozwiązania prawne dziś uzasadnione, moga okazać się nieprzystającymi do rzeczywistości w niedalekiej przyszłości.

Wiele z przedstawionych tu przykładów ma charakter hipotetyczny, niejednokrotnie zbliżajacy sie do science fiction. Ale, czerpiąc z historii - nie sposób nie zastanawiać się, jak długo? Tak jak w przypadku wszystkich innych przełomowych wynalazków czy technologii, tak i te związane z nowoczesnym, wspomaganym rozrodem najpierw budza strach i przerażenie oraz pobudzają wyobraźnię do tworzenia możliwych konsekwencji. Później jednak sa oswajane i ludzie uczą się z nimi żyć. Nawet z tym, że za sprawą medycyny matka nie jest już taka pewna.

${ }_{19}$ „Egg donation is not allowed in Sweden because of problems related to the motherhood issue but also out of concern for other types of problems, for example, psychic problems that may develop for the child".

${ }^{20}$ Pojedyncze inicjatywy jednostek sa mile widziane tylko i wyłącznie wtedy, kiedy służą utrzymaniu trwałości grupy. Pogodzenie trwałości systemu społecznego ze sprawnością działań jednostkowych jest, zdaniem Thomasa i Znanieckiego, jednym z głównych problemów społecznych (Znaniecki, Thomas 1975). 


\section{Bibliografia}

Fraga M. F. i in. (2005), Epigenetic differences arise during the lifetime of monozygotic twins, „Proceedings of the National Academy of Sciences USA”, vol. 102, no. 30, s. 10604-10609.

Fuszara M., Kurczewski J. (2007), From Marriage to Parenthood: Rethinking Parenthood In Times of Reproductive Innovation, [w:] M. Maclean (eds), Partenting after Parenting. Containing Conflict after Separation, Hart Publishing, Oxford and Portland Oregon, s. 41-62.

Golec-Grzymek (2009), Uwagi do nowelizacji Kodeksu rodzinnego i opiekuńczego $z$ 6.11.2008 r., „Monitor Prawniczy”, nr 19, s. 1053-1055.

Malinowski B. (1980), Dzieta, tom 2, PWN, Warszawa.

Raczek E. (2009), Nowelizacja Kodeksu rodzinnego i opiekuńczego, Rozdziału I. Pochodzenie dziecka (DzU 2008, $\mathrm{Nr}$ 220, poz. 1431) - uwagi biegtego genetyka sadowego, „Archiwum Medycyny Sądowej i Kryminologii”, Polskie Towarzystwo Medycyny Sądowej i Kryminologii, nr LIX, s. 134-135.

Saldeen A. (2000), Some Reflections on Children's Rights in a European Perspective, „Scandinavian Studies in Law”, vol. 39, s. 193-194.

Thomas W. I., Znaniecki F. (1975), Dezorganizacja a reorganizacja, [w:] J. Szacki (red.), Elementy teorii socjologicznych, PWN, Warszawa.

Ustawa z dnia 25 lutego 1964 r. Kodeks rodzinny i opiekuńczy.

Ustawa z dnia 6 listopada 2008 r. o zmianie ustawy - Kodeks rodzinny i opiekuńczy oraz niektórych innych ustaw.

\section{Netografia}

GH (2011), Ustalenie i zaprzeczenie macierzyństwa. Gdy matka nie jest pewna. www.usc.pl (dostęp: 21.02.2013).

Kampania „Powiedzieć i rozmawiać”, www.nasz-bocian.pl/powiedziecirozmawiacglowna (dostęp: 7.02.2013).

Ojciec zza grobu, dziecko.onet.pl/79504,6,9,ojciec_zza_grobu,artykul.html) (dostęp: 12.02.2013).

Országh K., Alternatywne formy adopcji, http://orszagh.com/adopcja/alternatywne-formy-adpocji (dostęp: 9.02.2013).

Szczepaniak A. (2009), Matka nie zawsze pewna, czyli rewolucyjne zmiany w polskim prawie rodzinnym, http://kancelaria-adwokacka-lodz.pl/index.php/pl/artykuy/70-matka-nie-zawsze-pewna-czyli-rewolucyjne-zmiany-w-polskim-prawie-rodzinnym (dostęp: 9.02.2013).

www.edziecko.pl/edziecko/1,80348,12486266,Adopcja_prenatalna__o_k.r.o.k_przed_ wazna_decyzja.html (dostęp: 7.02.2013).

emedicine.medscape.com/article/953492-overview (dostęp: 9.02.2013).

www.rynekzdrowia.pl/Uslugi-medyczne/Przeszczepiono-corkom-macice-matek,123376,8. html (dostęp: 3.02.2013.

www.wprost.pl/ar/383834/Elton-John-zostal-kolejny-raz-ojcem/ (dostęp: 9.02.2013). 


\section{„Mater semper certa est”? Parenthood medically redefined}

Not only contemporary Family Law of so called western civilization but also entire law systems or even cultural systems of many societies (e.g. matrylinear Triobrands) are based on a belief that parenthood is certain from mother's side. Medical advancements in in vitro insemination and constantly enhancing knowledge about genes made this arbitrary assumption questionable. Achievements of medical science in the field of parenthood experiments force us to redefine that term and take a closer look at social consequences of its current ambiguousness. Medical progress leaves the law behind which creates solutions that are questionable from the ethical standpoint. Moreover changes in the meaning and contents of the term family also leave the ones who are the most interested behind as well - what should be done when a newborn child has different genetic parents, different mother who gave birth, different upbringing parents and different ones under alimony obligations? What if each one of those parents claims newborn's rights. And what if parents of those "parents" want to be the child's grandparents...? The article below is an attempt to answer the question on possibilities to lawfully regulate parenthood matters and outline possible social consequences of such situations.

Key words: family law, parenthood, motherhood, fatherhood, surogate mother, infertility. 